\title{
Sequence stratigraphy and organic matter preservation of the Miocene to Pliocene Tatsunokuchi Formation, Iwate, Northeast Japan
}

\author{
Mamiko Yoshida*, Koichi Hoyanagi**, Haruka Kondo**, Hirobumi Inoue***, \\ Masayuki Oishi****, Hiroo Yoshida**** and Yukio Yanagisawa*****
}

Sequence stratigraphic and organic matter analyses were carried out on the Miocene to Pliocene Ishibane, Tatsunokuchi and Motohata formations that occur in Kitakami City, Iwate, Northeast Japan. These formations consist of nine facies and a depositional sequence that formed during a rise and fall of sea level. The proportions of vitrinite and cutinite are high in fluvial deposits of the lowstand systems tract. The total organic carbon content and the proportion of NFA (non-fluorescent amorphous kerogen) increase with transgression, because the sedimentary environment changed into an estuary with bottom anoxia. The proportions of vitrinite and cutinite increase in the highstand systems tract. These phenomena indicate the strong influence of river discharge.

Key words : estuary, organic matter, relative sea-level, sequence stratigraphy, Tatsunokuchi Formation

\section{Introduction}

The composition and quantity of sedimentary organic matter related to sea-level changes have been studied primarily in shelf to deep-sea deposits (e.g. Pellaton and Gorin, 2005), while there have been few such studies of estuary deposits. The transportation and preservation of organic matter in an estuary are influenced by river discharge, the inflow of seawater, and bottom conditions. The present study addresses the relationship between sequence stratigraphy and organic matter preservation in an incised-valley system, via study of the Tatsunokuchi

Received : November 8, 2006 ; Accepted : January 4, 2007

* Graduate School of Science and Technology, Niigata University, 8050 Ikarashi 2-cho Niigata, 950-2181, Japan

** Department of Geology, Faculty of Science, Shinshu University, 3-1-1 Asahi, Matsumoto, Nagano, 390-8621, Japan

*** Former-Graduate School of Life and Environmental Sciences, University of Tsukuba, 1-1-1 Ten-nodai, Tsukuba, 305-8572, Japan

**** Iwate Prefectural Museum, 34 Ueda-Matsuyashiki, Morioka, Iwate 020-01, Japan

***** Geological Survey of Japan, AIST, Chuo-7, 1-1-1 Higashi, Tsukuba, 305-8567, Japan
Formation in Kitakami City, Iwate, Northeast Japan (Fig. 1).

Miocene and Pliocene deposits in the study area are divided into the Ishibane, Tatsunokuchi and Motohata formations, in ascending order (Fig. 2). The Tatsunokuchi Formation formed during the late Miocene to early Pliocene (Yanagisawa, 1998) ; it conformably overlies the Ishibane Formation and is unconformably overlain by the Motohata Formation (Oishi et al., 1996, 1998). The Ishibane and Motohata formations consist of non-marine deposits, while the Tatsunokuchi Formation is composed of intrabay deposits (Oishi et al., 1996).

\section{Facies descriptions and interpretations}

\section{Facies A : braided river channel}

Facies A ( $3 \mathrm{~m}$ thick) consists of poorly sorted, clastsupported and pebble-size conglomerate. Conglomerate clasts are rounded to subrounded. The matrix consists of coarse-grained sandstone. This facies exhibits normal grading and has channelized bases. Facies A erosionally overlies Facies C.

Facies A is interpreted as fluvial channel deposits, because they exhibit channelized bases, conglomerate fa- 


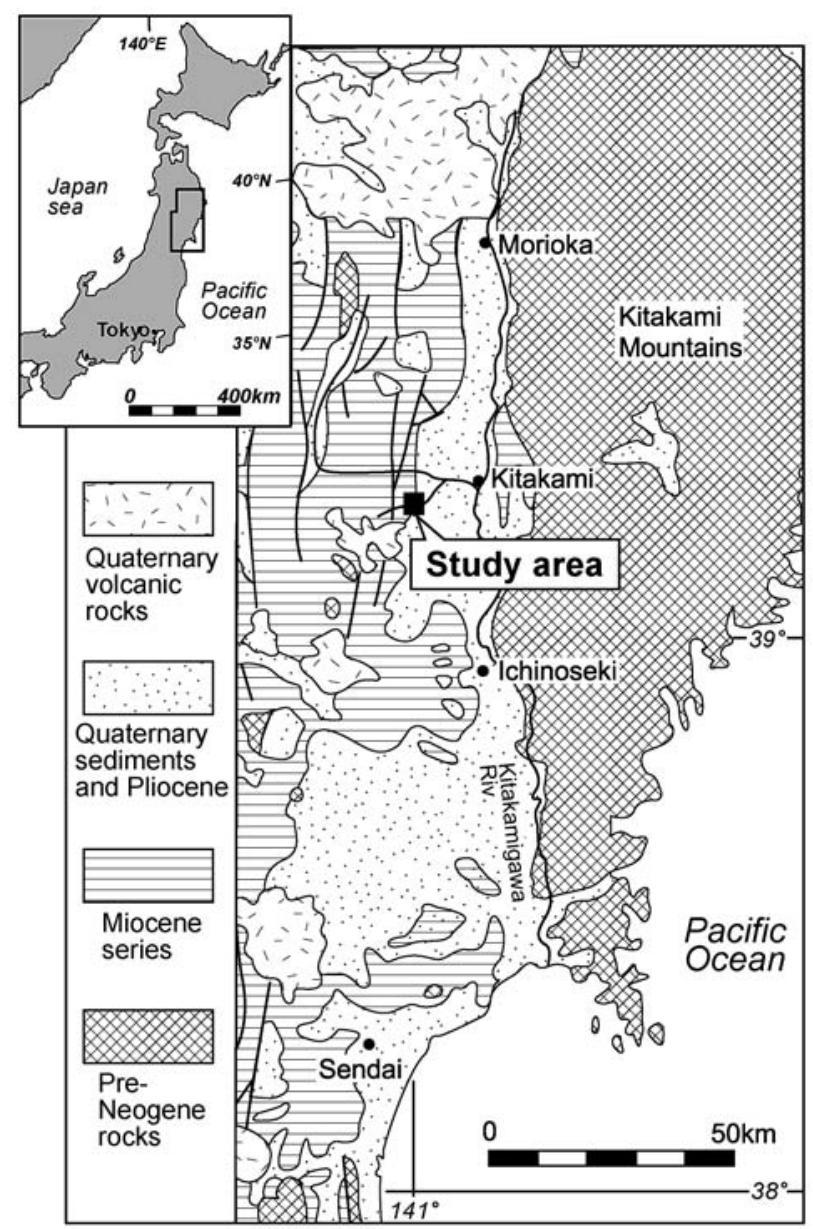

Fig. 1 Location map of the study area and geologic setting around the study area (modified from Oishi et al., 1996).

cies and lack evidence of biological activity. Furthermore, this facies is characterized by the aggradation of thin channel-fill deposits and lacks mudstone beds. Braided river is characterized by abandoned channels and its rapid migration limits the accumulation of finer material (Walker and Cant, 1984). Therefore, Facies A is interpreted as fluvial channel deposits of a braided river system.

\section{Facies B : meandering river channel}

Facies B (0.6-6.6 m thick) consists of poorly sorted and fine to very coarse-grained sandstone, and matrixsupported pebble conglomerate. It exhibits an upwardfining facies succession from conglomerate to crossbedded sandstone. Conglomerate clasts are subrounded to subangular. Conglomerate beds exhibit channelized bases and normal grading. Sandstone beds have normal grading and trough-stratification. Furthermore, small-

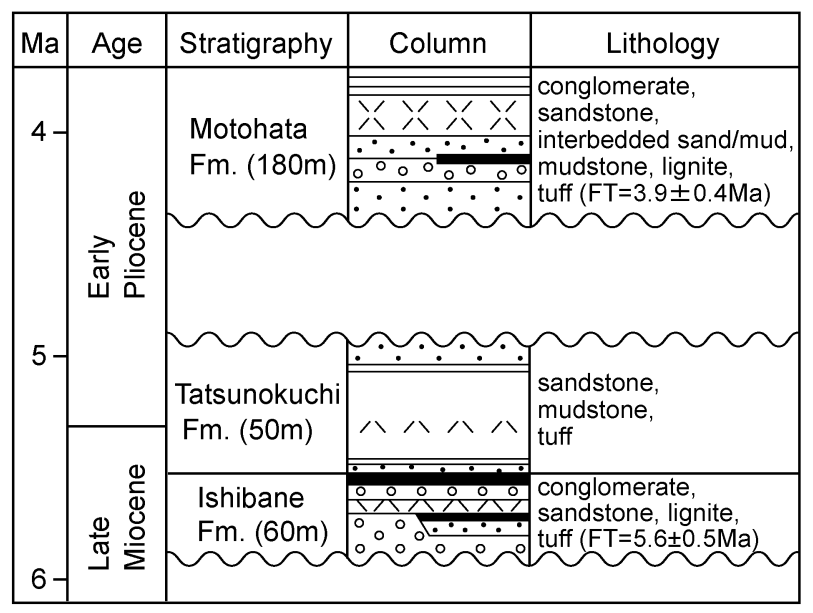

Fig. 2 Stratigraphy and age of the Ishibane, Tatsunokuchi and Motohata formations (modified from Oishi et al., 1998). Fm. : Formation ; FT : Fission-track age.

scale trough-type cross-laminae are present within large cross-stratification (epsilon cross-stratification). Facies B erosionally overlie Facies $\mathrm{H}$ and $\mathrm{E}$.

Facies B is interpreted as fluvial channel deposits, because it exhibits a unidirectional flow structure, a channelized base and a lack of evidence for biological activity. This facies also exhibits upward-fining and is overlain by muddy deposits of Facies C. Meandering river deposits are characterized by an upward-fining succession, the dominance of muddy deposits and the presence of epsilon cross-stratification formed by the lateral accretion of a point bar (Walker and Cant, 1984). Therefore, Facies B is considered to be fluvial channel deposits of a meandering river system.

\section{Facies $\mathbf{C}$ : flood plain}

Facies C (1-5 m thick) consists of claystone, siltstone, very fine-grained sandstone and lignite. The mudstone is light to dark gray, and contains obscure parallel laminae and water-escape structures. Sandstone beds contain intercalated lenticular gravel beds with channelized bases. Many root traces and wood fragments are present. Bioturbation is rare, but Teredolites is present. Facies C gradually overlies Facies B.

Facies $\mathrm{C}$ is inferred to represent the flood plain of a meandering river system, because it is muddy, includes many root traces and overlies meandering-river-channel deposits. The lenticular gravel beds with channelized bases represent chute-channel deposits.

Facies D : lake

Facies D (60 cm thick) consists of greenish gray silt- 
stone. This facies is generally structureless, except for the local presence of indistinct parallel laminae and waterescape structures. Many leaf fossils and wood fragments are present. Facies D gradually overlies Facies B.

Facies D is interpreted to represent deposition from suspension in stagnant waters, because it contains massive silt with many leaf fossils. An overall lack of bioturbation suggests a non-marine environment. Facies D is inferred to have been deposited in a freshwater lake, which was too deep for land plants to live.

\section{Facies E : tidal flat}

Facies E (4.4-5.0 m thick) mainly consists of fine- to medium-grained, massive sandstone and interbedded very fine- to fine-grained sandstone and siltstone, and contains medium-grained cross-bedded sandstone. The massive sandstone is poorly sorted. The interbedded sandstone and siltstone show flaser and wavy bedding. Current ripples and wave-ripple cross laminae with mud drapes are present. Paleocurrent directions are toward the south or northeast. The large cross-bedded sandstone $(70 \mathrm{~cm}$ thick) is moderately well-sorted, and exhibits a channelized base and foreset laminae. Paleocurrent directions are toward the northeast. Intense bioturbation and large trace fossils, including Ophiomorpha, Thalassinoides and Skolithos, are present. Facies E gradually changes to Facies $\mathrm{G}$ and I.

The occurrence of mud drapes on ripples, bidirectional paleocurrents and flaser to wavy bedding characterizes tide-influenced settings (Dalrymple et al., 1992). Large trace fossils and intense bioturbation are evidence for an oxic marine habitat where benthic organisms were active. Therefore, Facies D is interpreted as tidal flat deposits. The large cross bedded sandstone is inferred to represent tidal creek deposits formed by flood tides, based on their channelized bases and landward-directed paleocurrents.

Facies F : salt marsh

Facies F (0.8-1.7 m thick) consists of light to dark gray and greenish gray siltstone. This facies is mostly structureless and contains water-escape structures. It is characterized by the presence of many root traces, wood fragments and pine cone fossils. Bioturbation is moderate to rare. Rosselia is present. Facies F gradually overlies Facies $\mathrm{G}$ and $\mathrm{E}$, and is erosionally overlain by Facies I.

Facies $\mathrm{F}$ is interpreted to have been deposited in a muddy marsh environment on land, because this facies consists of siltstone with many root traces. Bioturbation and trace fossils also reflect the influence of seawater. Therefore, Facies $\mathrm{D}$ is considered to be salt marsh deposits. Facies G : estuarine central basin

Facies G (1.4-16.7 m thick) mainly consists of bluish, light to dark gray claystone and siltstone, and contains intercalated thin, very fine- to fine-grained sandstone beds. Pebbles are present in thin sandstone beds. This facies has obscure parallel laminae with weak bioturbation. Small trace fossils, such as Chondrites, are present. Many shell fragments are scattered throughout Facies G. Facies $\mathrm{G}$ sharply overlies Facies D and gradually changes to Facies I.

The fine-grained deposits imply that deposition occurred in a low-energy environment. The presence of shell fragments and bioturbation indicate a seawaterinfluenced environment. These characteristics imply that Facies $G$ was deposited in an estuarine central basin (Dalrymple et al., 1992).

Facies $\mathbf{H}$ : tidal channel or flood tidal delta

Facies $\mathrm{H}$ ( $1 \mathrm{~m}$ thick) consists of coarse-grained and well to moderately sorted sandstone. This facies shows large foreset laminae and normal grading. Paleocurrents flowed toward the northeast. Macaronichnus occurs throughout Facies H. Facies $\mathrm{H}$ erosionally overlies Facies F.

Facies $\mathrm{H}$ is interpreted as tidal channel or flood tidal delta deposits. This interpretation is based on landward paleocurrents, well-sorted and large cross bedded sandstone and erosional bases. The trace fossil Macaronichnus indicates a sedimentary environment within the upper subtidal to lower intertidal zones (Clifton and Thompson, 1978).

\section{Facies I : transgressive estuary (lag deposits)}

Facies I (less than $45 \mathrm{~cm}$ thick) mainly consists of very poorly sorted and fine-grained sandstone, and contains subrounded, pebble-size conglomerate in its basal part. This facies is structureless and shows intense bioturbation. Facies I is gradually overlain by Facies $\mathrm{E}$ or $\mathrm{G}$ and erosionally overlies Facies $\mathrm{C}$ or $\mathrm{F}$ for the most part.

Facies $\mathrm{C}$ and $\mathrm{F}$ are inferred to have been deposited in shallower environments than Facies E and G. These facies changes imply transgression. Therefore, Facies I is considered to consist of transgressive-lag deposits that were formed by tidal erosion within estuary environments during a transgression. Furthermore, the erosional surface is inferred to be a bay-ravinement surface (Nummedal and Swift, 1987).

\section{TOC content and organic matter composition}

The total organic carbon (TOC) content ranges from 0.12 to $3.69 \%$ (Fig. 3).

Organic matter consists of vitrinite (3.33 to $52.33 \%$ ), fusinite $(0.33$ to $56.67 \%)$, cutinite (6.67 to $29.00 \%)$, 


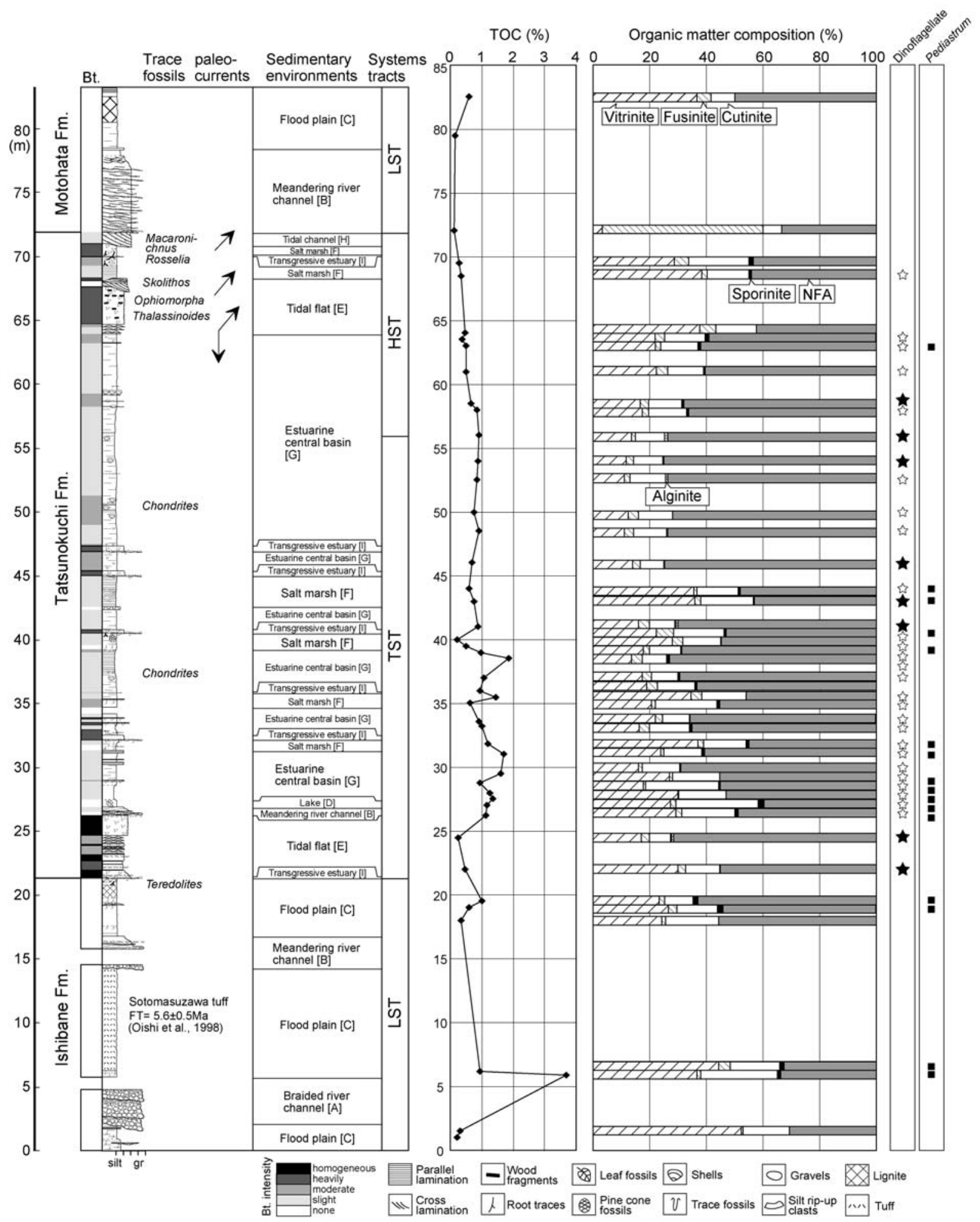

Fig. 3 Summarized column for the Ishibane, Tatsunokuchi and Motohata formations showing facies, trace fossils, paleocurrent directions, sedimentary environments, systems tracts, total organic carbon (TOC) content and organic matter composition. Facies codes are in square brackets. Square marks show the presence of Pediastrum. Black and white stars show more than and less than 20 specimens of dinoflagellate cysts, respectively. Bt. : Bioturbation. 
sporinite (less than 2.00\%) and NFA (non-fluorescent amorphous kerogen) (30.67 to $75.00 \%$ ). A few broken Pediastrum in the freshwater alginite are present on some slides. Well-preserved dinoflagellate cysts are present on all slides of the estuary deposits.

\section{Facies succession and sequence stratigraphic interpretation}

Fluvial deposits of the Ishibane Formation unconformably overlie basement rocks of the Hishinai Formation (Oishi et al., 1998). The boundary between these formations is thought to be a sequence boundary (e.g. Posamentier and Vail, 1988) that was formed by fluvial erosion during a sea-level fall. In embayment settings, the bay-ravinement surface (Nummedal and Swift, 1987), which lies between fluvial deposits of the Ishibane Formation and estuary deposits of the Tatsunokuchi Formation, corresponds to a transgressive surface. Therefore, fluvial deposits above the sequence boundary and below the transgressive surface are inferred to represent a lowstand systems tract (e.g. Posamentier and Vail, 1988) (Fig. 3).

The lower part of the Tatsunokuchi Formation is mainly composed of tidal flat and estuarine central basin deposits, in ascending order. This facies succession shows the expansion of the estuary during transgression. The tidal flat had an oxic bottom, based on the presence of intense bioturbation and large trace fossils. In contrast, the estuarine central basin had an anoxic bottom, because bioturbation declined. A laterally traceable marine bed with molluscs is shown in the geological cross section (Oishi et al., 1998) of the Kitakami Lowland. This horizon is interpreted as a maximum flooding surface (MFS), in which the coastline moved to its most inland site. The MFS correlates with the horizon about $56 \mathrm{~m}$ above the base of the stratigraphic column in the study area (Fig. 3). Therefore, estuary deposits of the Tatsunokuchi Formation below and above the MFS are regarded as a transgressive systems tract (TST) and a highstand systems tract (HST) (e.g. Posamentier and Vail, 1988), respectively. The HST is mainly composed of an estuarine central basin and tidal flat deposits, in ascending order. Bioturbation increases and large trace fossils are present in the upper part of this interval. These phenomena indicate that the estuarine bottom became oxic with regression.

The Tatsunokuchi Formation is unconformably overlain by fluvial deposits of the Motohata Formation (Oishi et al., 1998). This unconformity is inferred to be a sequence boundary and the fluvial deposits are regarded as an LST. An overall lack of bioturbation in this interval shows that the activity of benthic organisms was restricted, due to the stress imposed by fresh water.

\section{Organic matter preservation}

\section{Lowstand systems tract (Ishibane and Motohata forma- tions)}

The TOC content of LST fluvial deposits is relatively low (about 0.5\%) (Fig. 3). This reflects the fact that organic matter was unlikely to be preserved under oxic bottom conditions. The organic matter composition of fluvial deposits is characterized by high proportions of vitrinite, fusinite, cutinite and sporinite, which are coarsegrained and terrestrial in origin, and by the occurrence of the freshwater alga Pediastrum. These support the conclusions based of facies analysis.

Transgressive and highstand systems tracts (Tatsunokuchi Formation)

The TOC content of the TST estuary deposits increased from about $0.5 \%$ to $1.0 \%$ during transgression (Fig. 3). The TOC trend reflects the estuarine bottom conditions changing to anoxic, which is suitable for preserving organic matter. The proportions of vitrinite, cutinite and sporinite decrease toward the MFS, whereas the NFA increases. However, Omura et al. (2000) conducted organic matter analysis of the Pleistocene Uonuma Formation in Niigata Prefecture, and reported that the proportion of NFA was low in estuarine central basin deposits. Tyson (1995) stated that a portion of the amorphous organic matter was produced by benthic bacteria under anoxic marine conditions. Organic matter in the Tatsunokuchi Formation, therefore, might have been preserved as NFA in sediments under anoxic bottom conditions. Marine dinoflagellate cysts are well-preserved throughout the TST deposits, and their proportion increases toward the MFS. These phenomena suggest that the influence of marine water increased in response to the sea-level rise.

The TOC content of the HST deposits decreased to about $0.5 \%$ during regression, and the proportions of vitrinite, cutinite and sporinite increased. These phenomena indicate the increased influence of river discharge, which brought in terrigenous organic matter.

\section{References}

Clifton, H.E. and Thompson, J.K., 1978 : Macaronichnes segregates: A feeding structure of shallow marine polychaetes. Jour. Sediment. Petrol., 48, 1293-1302.

Dalrymple, R.W., Zaitlin, B.A. and Boyd, R., 1992 : Estuarine facies models : conceptual basis and stratigraphic 
implications. Jour. Sedim. Petrol., 62, 1130-1146.

Nummedal, D. and Swift, D.J.P., 1987 : Transgressive stratigraphy at sequence-bounding unconformities : some principles derived from Holocene and Cretaceous examples. In Nummendal, D., Pilkey, O.H., and Howard, J. D., eds., Sea-level fluctuation and coastal evolution, SEPM Spec. Publ., no. 42, 241-260, SEPM, Tulsa.

Oishi, M., Yoshida, H. and Kim, K.N., 1998: The PlioPleistocene formations of the Waga and Geto River area in the Kitakami Lowland, Northeast Japan. Res. Rep. Iwate Pref. Mus., 14, 5-20.

Oishi, M., Yoshida, H., Kim, K.N., Yanagisawa, Y. and Sugiyama, R., 1996 : Geology and ages of the PlioPleistocene sedimentary rocks on the western margin of the Katakami Lowland, Northeast Japan : re-examination of the so-called "Motohata Formation". Jour. Geol. Soc. Japan, 102, 330-345.

Omura, A., Ikedzu, D. and Hoyanagi, K., 2000 : An implication of depositional environments with reference to maceral compositions from the Pliocene and Pleistocene sediments in the Higashikubiki Hills, Niigata Prefecture, central Japan. Jour. Sediment. Soc. Japan, no. 52,
43-52.

Pellaton, C. and Gorin, G.E., 2005 : The Miocene New Jersey passive margin as a model for the distribution of sedimentary organic matter in siliciclastic deposites. Jour. Sediment. Res., 75, 1011-1027.

Posamentier, H.W. and Vail, R.P., 1988 : Eustatic controls on clastic deposition II- sequence and systems tract models. In Wilgus, C.K., Hastings, B.S., Kendall, C.G., St, C., Posamentier, H.W., Ross, C.A., and Van Wagoner, J.C., eds., Sea-level changes : an integrated approach, SEPM Spec. Publ., no. 42, 915-937, SEPM, Tulsa.

Tyson, R.V., 1995 : Sedimentary Organic Matter : Organic Facies and Palynofacies. Chapman and Hall, London, $615 \mathrm{p}$.

Walker, R.G. and Cant, D.J., 1984 : Sandy fluvial systems. In Walker, R.G., ed., Facies models 2nd edition, 71-89, Geol. Asso. Can., St. John's.

Yanagisawa, Y., 1998 : Diatom biostratigraphy of the Neogene Tatsunokuchi Formation in the western Kitakami City, Iwate Prefecture, Japan. Res. Rep. Iwate Pref. Mus., 14, 29-36.

\section{中新統〜鮮新統竜の口層のシーケンス層序と有機物保存}

吉田 真見子・保柳 康一・近藤 はるか・井上 博文・大石 雅之・吉田 裕生・柳沢 幸夫, 2007, 堆積学研究, No. 64, 21-26

Yoshida, M., Hoyanagi, K., Koudo, H., Inoue, H., Oishi, M., Yoshida, H. and Yanagisawa, Y. :

Sequence stratigraphy and organic matter preservation of the Miocene to

Pliocene Tatsunokuchi Formation, Iwate, Northeast Japan

Jour. Sed. Soc. Japan, No. 64, 21-26

岩手県北上市に分布する中新統～鮮新統石羽根・竜の口・本畑層において，シーケンス層序解析 と有機物分析を行った。これらの地層は，一回の海進・海退に伴って形成された河川とエスチュア リーの堆積物から構成される。低海水準期堆積体を構成する河川堆積物では, 陸上高等植物を起源 とする vitrinite と cutinite が高い割合を示す。一方，海進期堆積体のエスチュアリー堆積物では， marine alginite や無定形有機物の割合が最大汇濫面に向かって増加する傾向を示す。また，高海水 準期堆積体になると, 再び vitrinite と cutinite の割合が上方に増加する。以上の結果は, 有機物組成 が海進・海退に伴って变化する河川の影響や底層の酸化還元性に強く影響を受けることを示す。 